\title{
SUPPORT OF THE TERRITORIAL INTEGRITY OF AZERBAIJAN \\ BY UKRAINE DURING THE ESCALATION PERIOD IN NAGORNO-KARABAKH
}

\author{
Mubariz Rahimli \\ Postgraduate Student at the Department of Political Science, Faculty of Philosophy, \\ V. N. Karazin Kharkiv National University, Ukraine \\ e-mail: rahimlimubariz@gmail.com,orcid.org/0000-0001-5999-1062
}

\begin{abstract}
Summary
The object of this article is to study historical reasons for the escalation in Nagorno-Karabakh, to identify possible scenarios for the development of the conflict, considering the support of the territorial integrity of Azerbaijan by Ukraine. A large-scale war is certainly not beneficial to anyone. It is disadvantageous for Azerbaijan because the country does not lay claim to the territory of Armenia; Azerbaijan only wants its lands to be liberated. The investigation sees into the main positions of Ukraine in regards to the conflict and its support of the integrity of Azerbaijan's territory. It also outlines the main scenarios for the possible further development of relations between Azerbaijan and Armenia and highlights the viewpoints of both parties. Methods that were used in the research are as follows: general scientific method (analysis and synthesis, induction and deduction), method of theoretical research (from abstract to concrete), historical method. It was determined that Ukraine's stand regarding Azerbaijan is enforced by its consistent support in the Donbas region situation and the annexation of Crimea. The article also identifies the main points of support from Turkey, as well as other countries' standpoints. The conflict will only be settled if Azerbaijan and Armenia reach a consensus through negotiations, taking into consideration each other's principles of territorial integrity and perspectives. The resumption of the conflict is bolstered by the aggravated economic situation in the wake of the pandemic.
\end{abstract}

Keywords: Nagorno-Karabakh, conflict, military actions, Armenia, Azerbaijan, territorial integrity, Ukraine.

DOI: https://doi.org/10.23856/4028

\section{Introduction}

Intensive hostilities have been going on between the armed forces of Azerbaijan and Armenia at the contact line in the self-proclaimed Nagorno-Karabakh since September 27, 2020. This is the most serious armed conflict in the region since April 2016. The hotbed of tension covers entire Nagorno-Karabakh, the territory of which Armenia and Azerbaijan have been quarreling for more than 30 years. The history of the Nagorno-Karabakh conflict has been dragging on for several years. It is extremely difficult to foresee the development of the conflict. We find it necessary to outline the history of Nagorno-Karabakh and to identify distinctive features of the current escalation between Armenia and Azerbaijan.

Unlike many countries of the world, after the escalation of the conflict in Nagorno-Karabakh, Ukraine took Baku's side, which happened because Ukraine and Azerbaijan consistently support each other in the restoration of sovereignty and territorial integrity within internationally recognized borders. 


\section{The main reasons for the escalation in Nagorno-Karabakh}

Nagorno-Karabakh is an area in the South Caucasus, located between modern Azerbaijan and Armenia. At the beginning of the 19th century, the Russian Empire won the war with Qajar Iran (Persia back then), and according to the Treaty of Gulistan (1813), and later the Treaty of Turkmenchay (1928), the territories of Khanates of the Caucasus (Karabakh, Ganja, Sheki, Iravan, etc., in particular), the modern territories of Armenia and Azerbaijan, became its part. By and large, these treaties laid the ground for the modern Nagorno-Karabakh conflict.

After the revolution of 1917, three national republics (they became Soviet only in 1922) formed in the Caucasus: Azerbaijan, Georgia, and Armenia. They united into the Transcaucasian Federation, which disintegrated in May 1918 due to the territorial claims of Armenia to Georgia and Azerbaijan, and to Karabakh, in particular, which then was joint to Azerbaijan. The independence of the Transcaucasian republics lasted a little over two years, after which the Soviet government imposed control on them.

One of the principles of the policy of the Soviet Union then-leader, Joseph Stalin, was to divide the same people between different republics. After the Sovietization of Armenia and Azerbaijan, by the decision of the Caucasian Bureau of the CC RCP (b) of July 4, 1921, it was regulated to turn Nagorno-Karabakh over to the Armenian SSR, but the final decision was left to the Central Committee of the RCP (b). However, with a new decision of July 5, it was kept as a part of the Azerbaijan SSR with the granting of broad regional autonomy (Collection of documents and materials, 1991).

On July 7, 1923, the Armenian-populated part of Nagorno-Karabakh was formed into the Autonomous Region of Nagorno-Karabakh (ARNK) with the center in the Khankendi village (later renamed to Stepanakert) (Decree of the AzCEC of Soviets, 1923). Initially, ARNK bordered on the Armenian SSR, but by the end of the 1930s, the common border had disappeared. Subsequently, it was separated from Armenia by the so-called Lachin corridor (Sputnik Azerbaydzhan, 2015).

In the late 1980s, the long-standing contradictions between Armenia and Azerbaijan resumed with a renewed vigor. The authorities of Nagorno-Karabakh sought to unite with Armenia, that supported this position. In the meantime, Azerbaijan and central authorities of the USSR were against this scenario. In 1988, the parliament of the ARNK adopted a resolution concerning joining Armenia, and two years later, the Armenian SSR unilaterally annexed Nagorno-Karabakh. In 1991, the ARNK proclaimed its independence. In response to it, Azerbaijan began an economic blockade of the ARNK at first, and afterward, the confrontation between the two Soviet republics became armed. Russia came to Armenia's aid, with which they concluded The Treaty on Friendship, Cooperation, and Security at the end of 1991. Active hostilities between the countries continued until 1994. As a result, Armenia, with the support of Russian troops, occupied not only Nagorno-Karabakh but also onefifth of Azerbaijan's territory, including the aforementioned Lachin corridor. Armenia and Azerbaijan were not able to settle amicably during this whole time. Yerevan demanded the inclusion of Nagorno-Karabakh as a part of the country and conceded the return of the rest of the occupied territories (seven districts outside the administrative boundaries of the ARNK) to Azerbaijan. Baku, in its turn, expected Armenia to return its territories and was ready to provide Nagorno-Karabakh with maximum autonomy, as long as the area was considered a part of Azerbaijan. 


\section{Particularities of the escalation in Nagorno-Karabakh in $\mathbf{2 0 2 0}$}

After the change of power in 2018, Armenia tried to renew negotiations in terms of the OSCE Minsk Group by adding Nagorno-Karabakh as a separate participant, which was unacceptable for Baku. The negotiations were frozen, and the tension between the parties increased, which became the reason for the current aggravation. Back in 2018, after the revolution in Armenia, the violence almost faded away, thanks to instructions from both leaders and a promise to "prepare both societies for peace" in 2019, which has been ignored.

The current escalation is the most serious one since the war in 1992-1994. We are talking about a full-scale war - the conflict is not taking place in the local clashes mode, but is running along the entire line of contact. This is the second flare-up between Armenia and Azerbaijan over Nagorno-Karabakh in 2020. The first one happened on the administrative border of Azerbaijan and Armenia in July, but it stopped relatively fast, although dozens of deaths were officially reported on both sides. Besides, the warfare is taking place against the background of the coronavirus pandemic, because of which both Armenia and Azerbaijan are experiencing economic difficulties. Experts explained the July aggravation by the desire of Yerevan and Baku to distract their peoples from these problems.

According to the Azerbaijani Ministry of Defense, Armenian troops fired at several settlements along the border of the two countries with mortars and artillery on September 27, 2020. We are talking about several villages in the areas controlled by the Azerbaijani authorities. The Armenian Defense Ministry, for its part, holds Azerbaijan responsible for the clashes. According to Yerevan's data, the Azerbaijani army launched strikes along the entire length of the contact between the troops and was the first to have started applying fire to the territory of Nagorno-Karabakh (Fig. 1).

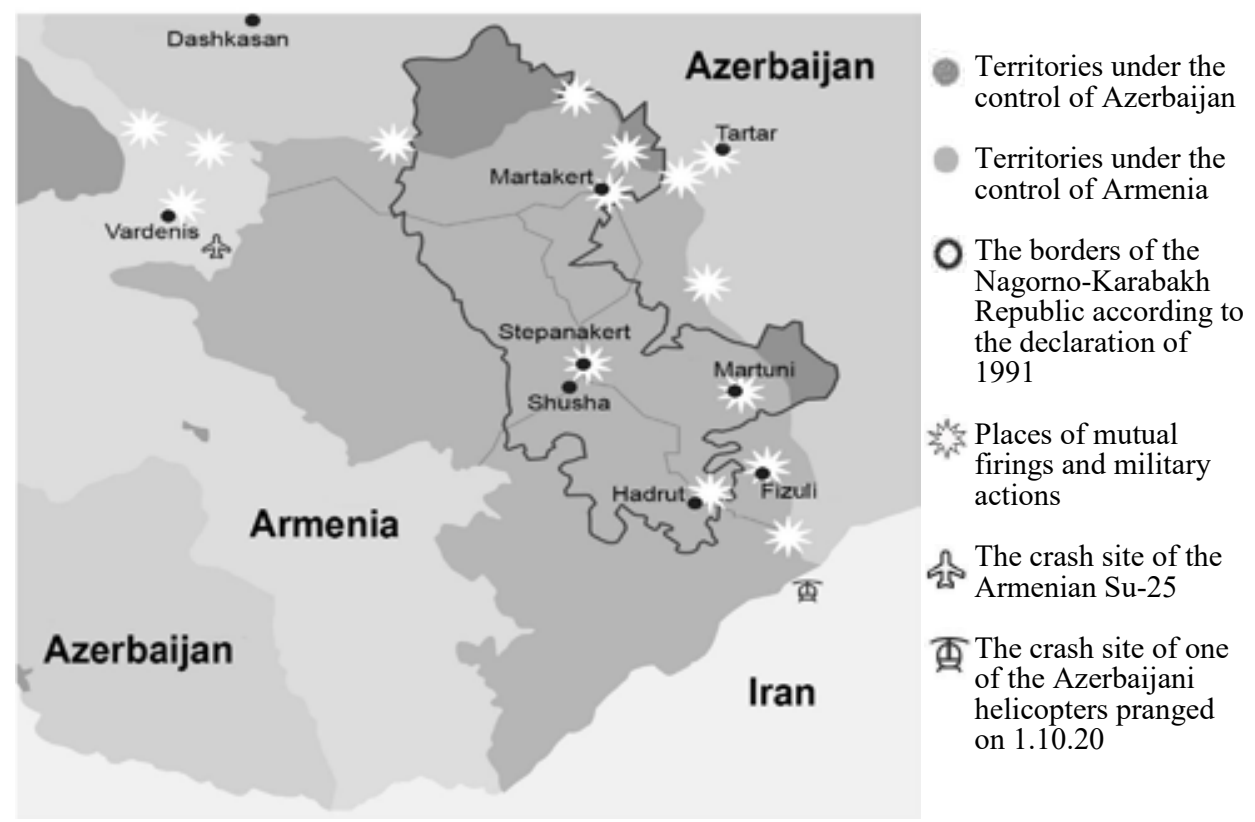

Figure 1. Cartogram of clashes in Nagorno-Karabakh as of 01.10.2020

Source: The Ministries of Defense of Armenia and Azerbaijan, 2020 
General martial law was introduced in Armenia and partial martial law - in Azerbaijan accordingly; curfews were imposed in both countries. Yerevan also announced general mobilization. On September 28, the parties officially reported dozens of military personnel killed on each side. Yerevan and Baku started confrontation on international platforms as well.

In the following days, military clashes on the line of contact carried on. Both sides were announcing the disposal of the armored vehicles, artillery, and drones. In Baku, there also was news about the conquest of several strategically important heights in the Talish village area. The self-proclaimed regime in Nagorno-Karabakh introduced martial law. The head of the unrecognized republic, Arayik Harutyunyan, announced the general mobilization of people over 18 years old. Prime Minister of Armenia, Nikol Pashinyan, appealed to the people and called Baku's actions a declaration of war. Armenian hospitals simultaneously stopped routine patient admissions following the introduction of martial law in the country (BBC News, 2020).

The present escalation is unprecedented in scale. The bombings and the shootings are everywhere, along the entire perimeter of the border. And perhaps for the first time in many years, the military actions reached Stepanakert (the administrative center of Nagorno-Karabakh) (N. Ayrumyan, 2020).

It should be outlined that, based on the premises and the scale of the conflict, it is difficult to guess how calculated or planned the magnitude of this conflict escalation was. It seems that it was the element of surprise that provoked such a strong fire exchange. We consider significant and aggravating the fact that both sides did not see an opportunity to retreat, despite the lack of evidence of a major offensive operation, as in 2016. This shows a considerably high degree of combat readiness as well as the fact that the leaders of both countries found themselves in the pandemic situation during unfinished processes of power consolidation on their territories, missing out on the opportunity to take advantage of the three-year ceasefire and invest in peaceful strategies that would help resolve the present situation.

\section{Possible scenarios for the development of events in Nagorno-Karabakh}

Despite the intensity of the conflict evolvement, the parties have limited resources for a full-scale and long-term war (S. Pritchin, 2020). Although the economy of Azerbaijan is quite stable, the conduct of military operations along the entire length of the border is very costly, both in terms of human resources and finances (Table 1).

According to expert opinion, the current actions of Baku most likely pursue tactical goals, namely - the return of a part of the Azerbaijanian territories. As of October 2020, Azerbaijan managed to return more than ten villages in the Azerbaijani lands and the regional center of the Jebrail region, which were under the control of Armenia (The Ministry of Defense of Azerbaijan, 2020).

The balance of forces in Nagorno-Karabakh

\begin{tabular}{|l|c|c|c|}
\hline \multicolumn{1}{|c|}{ Resources } & Azerbaijan & Armenia & Nagorno-Karabakh \\
\hline $\begin{array}{l}\text { The number of active military } \\
\text { commitment, persons }\end{array}$ & 66950 & 44800 & $18000-20000$ \\
\hline Artillery assets, pcs. & 598 & 232 & 232 \\
\hline APC, pcs. & 568 & 130 & N/A \\
\hline Tanks, pcs. & 439 & 109 & $320-426$ \\
\hline IVF, pcs. & 216 & 231 & N/A \\
\hline
\end{tabular}

Source: International Institute for Strategic Studies, 2020 
According to Nersisyan, head of the Defense Research Department of Armenian Research \& Development Institute (ARDI), there are two scenarios for the development of events (L. Nersisyan, 2020). The first and the most likely one presupposes the end of hostilities, including the ones resulting from the pressure from third players, who do not want escalation. Nevertheless, the other scenario, foreseeing the possibility of the conflict getting out of control, should not be dismissed. The risk of escalation and involvement of Armenia's territory in the conflict remains as well as territories of third players' - Turkey and Russia, in particular. Whereas Ankara has been actively involved in the Nagorno-Karabakh conflict from the governor to the official levels since the July escalation, there are calls for help to Azerbaijan as a counterbalance to Armenia.

The main problem in the delaying of a peaceful settlement of the conflict lies in the complete distrust of the parties to each other, and there are sufficient grounds for this. There is a nationwide consensus in Armenia in regards to the inadmissibility of any concessions to Azerbaijan. Moreover, suspicions of readiness for such concessions can affect the profile of Armenian politicians. It is also essential that key world players, including the EU and the United States, recognize Armenia as an occupier, and they still openly support an agreement that would let Yerevan avoid the return of the territories inhabited by Armenians to Azerbaijan regardless. To this end, the West is looking for the compensators capable of changing Baku's position. This reality may not be pleasant, but it cannot be denied. Its cause lies in the complex and bloodstained history of the region, which makes the West believe that the restoration of Baku's control over Nagorno-Karabakh will have irreversible consequences.

The international community is deeply concerned about the escalation of the conflict in Nagorno-Karabakh. Thus, the co-chairmen of the OSCE Minsk Group, which includes the United States, Russia, and France, are preparing some new initiatives on the Karabakh settlement (A. Lyakin, 2020). The majority of countries and international organizations are making a call to Armenia and Azerbaijan for de-escalation. The only exception, as previously mentioned, is Turkey and France to some extent after the statement of President Emmanuel Macron (M. Gelikova, 2020).

Erdoğan said that Armenia had attacked Azerbaijan and called upon its withdrawal from the occupied territories. This statement can be evaluated as Turkey's attempt to raise its profile amid the conflict with Greece over the Eastern Mediterranean and Libya, where an active power redistribution is now taking place. President of Azerbaijan, Ilham Aliyev, in turn, said that the hostilities in Nagorno-Karabakh would last until Armenia had withdrawn its armed forces. Aliyev also criticized Macron's statements (K. Pankova, 2020).

\section{Position of Ukraine during the aggravation of the conflict between Azerbaijan and Armenia}

Ukraine's official position corresponds to that adopted at the UN level. Neither the independence of Nagorno-Karabakh nor the occupation of Azerbaijani territories by Armenia is recognized there. Apart from that, Kyiv and Baku are strategic partners. Ukraine and Azerbaijan established diplomatic relations at the official level since February 5, 1992. Many people in Azerbaijan, including political forces and the public, closely follow the events in Ukraine. First of all, Ukraine is a strategic partner of Azerbaijan and second of all, Azerbaijan has been through events alike to the occupation of Crimea and separatism in the east of Ukraine.

Ukraine expresses its support of the territorial integrity of Azerbaijan almost every time there is an aggravation in Nagorno-Karabakh. So in July 2020, when the situation in the 
South Caucasus heated up again, Ukraine once more took a stand in favor of "the sovereignty and territorial integrity of the Republic of Azerbaijan within its internationally recognized borders." It turned into a diplomatic scandal then: there was an outburst of protests under the building of the Ukrainian embassy in Yerevan, organized by the Armenian youth, outraged by Kyiv's stand.

Ukraine's principled stance in this matter is explained quite simply: for the Ukrainian authorities, the conflict in Nagorno-Karabakh is similar to the military operations in Donbas. However, solidarity with Baku in terms of its "territorial integrity" is not the only factor influencing Ukraine's position concerning Nagorno-Karabakh. Ukraine consistently supports the territorial integrity of Azerbaijan, just like Azerbaijan supported Ukrainian territorial integrity within internationally recognized borders, and this principle remains unchangeable for Ukraine (D. Kuleba, 2020).

We also consider it necessary to mention that relations with Turkey, which strongly supports Baku in all matters, also play an important role in the formation of the Ukrainian position. Here we emphasize that since 2014, relations between Ukraine and Turkey have developed extremely rapidly, having received the status of strategically important for Ukraine. In a situation where Ukraine is counting on a military alliance with Ankara, Azerbaijan's support as Turkey's junior partner looks natural.

Ukraine stands for a peaceful settlement of the conflict in Nagorno-Karabakh based on respect for international law and sovereignty, as well as the territorial integrity of Azerbaijan within its internationally recognized borders. Ukraine fully supports the actions of the OSCE Minsk Group Co-Chairs aimed at violence de-escalation and stabilization of the situation on the ground.

\section{Conclusions}

To sum up, the current escalation in Nagorno-Karabakh is yet another proof that both protracted and hot conflicts remain the main factor of instability, which jeopardizes security in the region and can lead to the resumption of hostilities and large human losses at any moment. Ukraine supports the territorial integrity of Azerbaijan and calls for a peaceful settlement of the conflict. New clashes only shed blood, bring grief, instigate provocations and myths, poison politics, and postpone the day of reconciliation. The parties need to negotiate the conflict, not to freeze it until the next clash. Armenia has declared its readiness for a peaceful settlement of the Karabakh conflict, but the government made clear that it is not ready to resolve the issue to the detriment of its national interests and security. However, there is a certain territorial integrity of Azerbaijan within the borders recognized by the international community. Thus, the parties should come to a reasonable solution to the unfolding conflict and direct their efforts to the strategic development of territories and their improvement.

\section{References}

Ayrumyan N. (2020). Azerbaydzhan i Armeniya voyuyut za Nagornyy Karabakh. Otkuda vzyalsya etot konflikt? [Azerbaijan and Armenia are fighting for Nagorno-Karabakh. Where did this conflict come from?]. URL: https://hromadske.ua/ru/posts/azerbajdzhan-i-armeniya-voyuyut-za-nagornyj-karabah-otkuda-vzyalsya-etot-konflikt (access date 28.09.20) [in Russian]. BBC News (2020). Nagornyy Karabakh: prostoye obyasneniye konflikta Armenii i Azerbaydzhana [The Nagorno-Karabakh: a simple explanation of the conflict between Armenia and 
Azerbaijan]. URL: https://www.bbc.com/ukrainian/features-54326645 (access date 28.09.20) [in Ukranian].

Decree of the AzCEC of Soviets "On the formation of the Autonomous Region of Nagorno-Karabakh» July 7, 1923. (1923). Source: Collection of legalizations and orders of the Workers 'and Peasants' Government of the ASSR for 1923, Baku. 1923. pp. 384-385 [Published in the newspaper «Bakinsky Rabochiy», No. 151 dated July 9, 1923].

Gelikova M. (2020). Frantsiya bespokoitsya: Makron zayavil ob opasnosti zayavleniy Turtsii [France worries: Macron says Turkey's statements are dangerous]. URL: https://www.gazeta.ru/ army/2020/09/30/13274419.shtml (access date 29.09.20) [in Russian].

International Institute for Strategic Studies (2020). URL:https://www.iiss.org/blogs/analysis/2020/10/armenia-azerbaijan-clashes (access date 28.09.20).

Kuleba D. (2020). Ukraina podderzhivayet territorialnuyu tselostnost Azerbaydzhana [Ukraine supports the territorial integrity of Azerbaijan]. URL: https://www.pravda.com.ua/ rus/news/2020/09/30/7268212/ (access date 01.10.20) [in Ukranian].

Lyakin A.(2020). Eksperty o prichinakh obostreniya na granitse Armenii i Azerbaydzhana [Experts about the causes of aggravation on the border of Armenia and Azerbaijan]. URL: https://www.bbc.com/russian/features-53424233 (access date 26.09.20) [in Russian].

Nersisyan L. (2020). Stsenarii razvitiya sobytiy v Nagornom Karabakhe [Scenarios for the actions development in epy Nagorno-Karabakh]. URL: https://www.rbc.ru/politics/06/10/2020/5f7067be9a794753f86fb7b5 (access date 26.09.20) [in Russian].

Pankova K. (2020). Makron raskritikoval zayavleniye Turtsii po Karabakhu [Macron criticized Turkey's statement on Karabakh]. URL: https://ria.ru/20201005/karabakh-1578245789.html? in $=t$ (access date 29.09.20) [in Russian].

Pritchin S. (2020). Osobennosti konflikta v Nagornom Karabakhe [The features of the conflict in Nagorno-Karabakh]. URL: https://www.rbc.ru/politics/ 06/10/2020/5f7067be9a794753f86fb7b5 (access date 28.09.20) [in Russian].

Resolution of the Caucasus Bureau of July 4, 1921 (1991). CPA IML, f. 85, op. 18, d. 58, l. 17. Resolution of July 5: CPA IML, f. 85, op. 18, d. 58, l. 18. // Nagorno-Karabakh in 1918-1923. Collection of documents and materials. Publishing house of the Academy of Sciences of Armenia. Yerevan, 1991, p. 649-650.

Sputnik Azerbaydzhan. (2015). 7 iyulya 1923 goda obrazovalas Avtonomnaya Oblast Nagornogo Karabakha [The Nagorno-Karabakh Autonomous Region was formed in 7 of July, 1923]. ULR: https://az.sputniknews.ru/event/20150707/400960448.html (access date 29.09.20) [in Russian].

The Ministries of Defense of Armenia and Azerbaijan. URL: https://mod.gov.az/en/news-791/ (access date 29.09.20). 